\title{
AKTIVNOSTI USMJERENE OSNAŽIVANJU NEPISMENIH RODITELJA ROMSKE DJECE
}

\author{
MAJA KUTNJAK \\ Osnovna škola Tomaša Goričanca, Mala Subotica, kontakt: maja.kutnjak@gmail.com
}

Primljeno: 1.9 .2015 .

Stručni rad

Prihvaćeno: 1.2.2016.

UDK: 316

Sažetak: U radu se raspravlja o povezanosti kvalitete obiteljskog okruženja i socioekonomskog statusa obitelji s osvrtom na utjecaj osiromašenog obiteljskog okruženja i obrazovne razine roditelja na rani razvoj djece. Posebno su izdvojeni rezultati nacionalnih istraživanja koja upućuju na to da su djeca romske nacionalne manjine jedna od najranjivijih skupina djece. U radu su također prikazane neke praktične smjernice za uključivanje nepismenih roditelja u obrazovanje djece te je istaknuto nekoliko programa namijenjenih djeci predškolske i rane školske dobi i njihovim roditeljima nižeg socioekonomskog statusa koji potiču razvoj pismenosti i drugih kognitivnih vještina kod djece te osnažuju roditelje za ispunjavanje zahtjeva roditeljske uloge.

Kao jedan od početnih koraka u procesu ostvarivanja suradnje i osnaživanja roditelja romske djece, u radu je predstavljeno istraživanje koje su proveli učitelji i romski pomagači Osnovne škole Tomaša Goričanca Mala Subotica u romskom naselju Piškorovec. Osnovni cilj istraživanja bio je utvrditi obrazovnu strukturu i razinu pismenosti odraslog stanovništva naselja Piškorovec kako bi se na temelju dobivenih rezultata mogao planirati program intervencije koji će biti temeljen na procijenjenim potrebama.

Ključne riječi: obiteljsko okruženje, rani razvoj djece, romska djeca, procjena pismenosti roditelja, uključivanje roditelja

\section{SOCIOEKONOMSKI STATUS OBITELJI I RAZVOJ DJETETA}

Povezanost različitih karakteristika obiteljskog okruženja s razvojnim ishodima djece je prilično opsežno dokumentirana i potkrijepljena kako u stranoj tako i u domaćoj literaturi. Pri tome je uočljiva konzistentnost nalaza o snažnom utjecaju socioekonomskog statusa obitelji ${ }^{1}$ (posebno razine obrazovanja roditelja i razine prihoda) i roditeljske uključenosti na uspješnost djeteta u obrazovanju ali i općenitoj kompetenciji nošenja s životnim izazovima (Bašić, 2009; Burušić i sur., 2010; FekonjaPeklaj i Marjanovič-Umek, 2011; Jokić i Ristić Dedić, 2010; Menheere i Hooge, 2010; Šućur i sur., 2015).

Istraživanja utjecaja obiteljskih, tj. roditeljskih karakteristika na razvoj djece najintenzivnija su u kontekstu školskog uspjeha djeteta, ranog napuštanja školovanja te rizika za razvoj poremećaja u ponašanju ali jednako tako i razvoja rane pismenosti kod djece te ranog kognitivnog razvoja. Opsežno istraživanje kojim je obuhvaćeno 48232 učenika četvrtih razreda i 46196 učenika osmih razreda osnovne škole u Hrvatskoj (Burušić i sur., 2010) pokazalo je da s porastom razine obrazovanja bilo kojeg od roditelja u svim ispitivanim predmetima razredne i predmetne nastave raste i obrazovno postignuće učenika. Posebno je zanimljiv nalaz spomenutog nacionalnog istraživanja da razlika između obrazovnog uspjeha djece te obrazovne kategorije roditelja s niskom stručnom spremom (NSS) i prve sljedeće više kategorije (SSS) na gotovo svim predmetima razredne i predmetne nastave predstavlja i najveću razliku u postignuću među svim susjednim obrazovnim kategorijama roditelja. Odnosno, već završeno srednjoškolsko obrazovanje povećava vjerojatnost boljeg dječjeg uspjeha dok daljnje visoko obrazovanje roditelja dodatno doprinosi poboljšanju učeničkih postignu-

1 Socioekonomski status (SES) shvaća se prema usuglašenoj tripartitnoj definiciji prirode SES-a koju su postavili Duncan, Featherman i Duncan (1972, prema Jokić i Ristić Dedić, 2010) po kojoj se on najčešće dijeli na: prihode, obrazovanje i zanimanje roditelja. Pri tome se obrazovanje roditelja smatra najstabilnijom komponentom SES-a jer utječe od početka djetetovog života i manje je promjenjiva u odnosu na druge dvije komponente (Jokić i Ristić Dedić, 2010). 
ća ali u nešto manjoj mjeri. Isti rezultat dobiven je i analizom podataka prikupljenih PISA istraživanjem provedenim u Hrvatskoj 2006. (Gregurović i Kuti, 2010). Utjecaj niskog SES obitelji (a posebno obrazovanje roditelja) snažno se povezuje i s preranim napuštanjem školovanja (Burušić, 2010; Ferić i sur., 2010; Matković, 2009). Međutim, u tim istraživanjima kao granica za identificiranje pojave preranog napuštanja školovanja (kao moguće krajnje posljedice, između ostalog, i vrlo niskih obrazovnih postignuća) uzima se ispadanje iz sustava obrazovanja prije završene srednje škole (budući da je razina očekivanog, tj. zadovoljavajućeg obrazovanja i kulturološki uvjetovana) pa se ovisno o tome je li roditelj završio srednju školu ili nije utvrđuje povezanost s obrazovnim postignućima djeteta i/ ili rizikom za prerano napuštanje školovanja. Iako se može logički pretpostaviti, postavlja se pitanje posljedica po djecu u situacijama kada roditelji nemaju završeno niti osnovno obrazovanje ili pak su nepismeni s posebnim osvrtom na mogućnosti aplikacije mjera za izjednačavanje šansi i prilika takve djece u obrazovnom sustavu. Kao što ćemo vidjeti kasnije, u pojedinim skupinama takve situacije su vrlo česte.

Pri osmišljavanju mjera za promjenu ili prevenciju mogućih negativnih reperkusija koje se javljaju u takvim situacijama trebalo bi uvažiti nalaze istraživanja koji upućuju na to da SES obitelji djeluje snažno, ali posredno na obrazovna postignuća $i$ uspjeh djeteta utječući na čimbenike kao što su roditeljska očekivanja, vjerovanja i ponašanje, stavovi prema školovanju, roditeljska uključenost i podrška, kvaliteta komunikacije između roditelja i djeteta, komunikacija roditelja i škole/učitelja (Davis-Keane, 2005; Kranželić Tavra i Bašić, 2005). Također, treba se osvrnuti i na druge čimbenike koji se povezuju s nižim obrazovnim postignućima i preranim napuštanjem školovanja kao što su: manjinski status u društvu, kulturološke razlike, značajke lokalne zajednice u kojoj pojedinac živi, viša razina obiteljskog stresa, ranije preuzimanje uloga odraslih, neki negativni obiteljski procesi i pojedina obilježja ličnosti pojedinca (Rosenthal, 1998).

$\mathrm{S}$ aspekta planiranja programa intervencije, posebno ranih intervencija u obiteljima niskog SES statusa, vrlo konkretne smjernice daju rezul- tati istraživanja o povezanosti karakteristika obitelji (s naglaskom na obrazovanje i financijsku situaciju obitelji što je najčešće proporcionalno povezano), obiteljske pismenosti i poticajnosti obiteljskog okruženja (eng. family literacy environment) s ranom pismenošću i jezično-govornim razvojem kod djece. Obiteljska pismenost definira se kao niz načina, aktivnosti i situacija u kojima članovi obitelji upotrebljavaju vještinu čitanja i pisanja, ali uključuje i različite obrazovne postupke kojima je cilj podizanje razine pismenosti svih članova obitelji (Knaflič, 2000 prema Stričević, 2007). Dostupnost edukativnih materijala kod kuće (prvenstveno knjiga), roditeljska podrška učenju kroz zajedničke aktivnosti (npr. zajedničko čitanje knjiga) i pristup resursima izvan obiteljskog doma (npr. knjižnici, kazalištu) igraju važnu ulogu u razvoju djetetove pismenosti i jezičnog razvoja (Carrol, 2013; Dearing i Taylor, 2007 prema Fekonja-Peklaj i Marjanovič-Umek, 2011). Roditelji iz siromašnih obitelji često nemaju financijskih sredstava da bi djeci osigurali dostupnost edukativnih materijala i igračaka kod kuće budući da su im prihodi jedva dostatni za podmirenje osnovnih životnih troškova (hrana, stanarina, obuća i odjeća) (Šućur i sur., 2015), a nerijetko nisu niti svjesni na koje sve načine mogu pomoći i podržati razvoj svog djeteta zbog nedovoljnog znanja o dječjem razvoju (Trikić, 2012). Autori kvalitetu obiteljskog okruženja procjenjuju prema dostupnosti primjerenih edukativnih materijala (npr. materijali za crtanje i pisanje, dječje slikovnice, križaljke), karakteristikama jezika kojim se roditelj koristi kada se obraća djetetu (npr. proširivanje ili transformiranje dječjih izjava, poticanje djeteta na pričanje priča $i$ prepričavanje događaja, postavljanje otvorenih i poticajnih pitanja), roditeljskoj uključenosti u igru i razgovor s djetetom (npr. poticanje simboličkih igara, zajedničko čitanje i raspravljanje o slikovnici) (Sénéchal i sur., 1998; Hoff, 2003; Raikes i sur., 2006; Rowe, 2008; ).

Djeci nepismenih roditelja podrška u razvoju rane pismenosti je nedostupna. Istraživanjima se utvrdilo da roditelji iz obitelji niskog SES statusa govore manje i s manje varijacija nego roditelji višeg SES statusa (Leseman i De Jong, 1998). Engle i Black (2008) primjećuju da u obiteljima 
nižeg SES statusa u govornom jeziku dominiraju zapovijedanje i izrazi jednostavnih gramatičkih struktura nauštrb objašnjavanja i poticanja interaktivne komunikacije. S druge strane, Hoff (2003) ukazuje na to da majke višeg SES statusa češće potiču dječji govor i osjetljivije su u prilagodbi na govor svog djeteta dok se, s druge strane, majke nižeg SES najčešće obraćaju djeci kada adresiraju dječje ponašanje, a mnogo rjeđe sa svrhom poticanja ili nastavljanja dječjeg govorenja. U obiteljima višeg SES statusa govori se više, koriste se različitiji izrazi i različite vrste riječi te se duže održava konverzaciju s djetetom vezano uz određenu temu (Hoff, 2003). Istovremeno ne treba zaboraviti niti da zajedničko čitanje pridonosi zbližavanju, emocionalnoj povezanosti i razvoju privrženosti kod djeteta čime se stvara platforma i za utjecaj na socio-emocionalni razvoj djeteta te internalizaciju (željenog) vrijednosnog sustava (Vasta i sur., 1998; Stričević, 2007).Nekoliko istraživanja je posebno istaknulo pozitivnu povezanost razine obrazovanja majke s ishodima jezično-govornog razvoja kod djeteta, konkretnije s varijabilnošću glagola i količinom riječi koje upotrebljava dijete u dobi od dvije godine kao i sa sposobnošću djeteta da konjugira i deklinira riječi u dobi od 3 godine (Silvén, Ahtola i Niemi, 2003). Navedeno se pripisuje opažanjima da obrazovanije majke koriste kompleksnije strategije u zajedničkom čitanju knjiga, uče djecu novim riječima i usmjeravaju pažnju djeteta na tekst koji se čita.

Bus, van IJzendoorn i Pellegrini (1995) pronalaze da je uz učestalost i kvalitetu zajedničkog čitanja vrlo snažan prediktor za razvoj rane dječje pismenosti, jezičnog razvoja i razumijevanja pročitanog i dob u kojem se djetetu počinje čitati. Mnogi autori zaključuju da izostanak izloženosti kvalitetnom jezičnom okruženju u ranoj dječjoj dobi povećava rizik za siromašna akademska postignuća u nižim razredima osnovne škole (Raikes i sur., 2006; Trikić, 2012; Carrol, 2013). Istraživanja jasno pokazuju da je čitanje već u dojenačkoj i ranoj dobi (0-3 godine) povezano $\mathrm{s}$ djetetovim jezičnim razvojem, a ono pak s razvo- jem vještina predvještina čitanja i pisanja koje potiču proces opismenjavanja (Grginič, 2007). Snažnu podršku ovome daju i brojna neurološka istraživanja koja prve godine života identificiraju kao kritično razdoblje za razvoj mozga budući da se $85 \%$ jezgre dječjeg mozga formira do treće godine života (uključujući i intrauterino razdoblje) što još više ističe ulogu ranih iskustava u dječjem razvoju (Trikić, 2012).

Longitudinalnim istraživanjem u Finskoj (Lyytinen, Laasko i Poikkeus, 1998) utvrdila se povezanost zajedničkog čitanja s razumijevanjem riječi i proizvodnjom simboličnih gesta kod djece u dobi od 14 mjeseci kao i s proizvodnjom riječi, duljinom rečenica i nekim kognitivnim vještinama kod djece u dobi od 24 mjeseca. Zanimljiv je nalaz evaluacijskog istraživanja programa Early Head Start ${ }^{2}$ koji govori da je zajedničko čitanje s djetetom $\mathrm{u}$ vrlo ranoj dobi pozitivno povezano $\mathrm{s}$ razvojnim ishodima djeteta neovisno o obrazovnoj razini roditelja, razini njihove pismenosti i količini knjiga dostupnima kod kuće (Raikes i sur., 2006). Posebno se istaknuo period u dobi djece od 14-24 mjeseci života kada se javlja tzv. efekt snježne grude (eng. "snow-ball effect") značajan za daljnji kognitivni i jezični razvoj te kasnija iskustva s čitanjem.

Sve veći broj empirijskih studija utvrđuje da se ranim uključivanjem djece u kvalitetne i sveobuhvatne programe za poticanje dječjeg razvoja mogu kompenzirati učinci izostanka poticajnog obiteljskog okruženja. Tim više su takvi programi najučinkovitiji što se njima intervenira u kritičnom razvojnom razdoblju djeteta, a kvalitetni programi ranih intervencija (i kasnije kvalitetni predškolski programi) najveći utjecaj imaju na ublažavanje negativnih posljedica upravo kod posebno ranjivih skupina djece (kao što su npr. vrlo siromašna djeca, djeca roditelja s niskom razinom obrazovanja, zanemarivana djeca, neurorizična djeca, djeca iz obitelji gdje su roditelji ovisnici, djeca iz jednoroditeljskih obitelji) (Raikes i sur., 2006; FekonjaPeklaj i Marjanovič-Umek, 2011; Trikić, 2012; Pećnik, 2013). Paralelnim ulaganjem u poboljšanje

2 Program Early Head Start nacionalni je program koji se od 1995. provodi diljem SAD-a. Namijenjen je trudnicama, dojenčadi i maloj djeci do 3. godine te njihovim roditeljima iz obitelji niskog SES nudeći sveobuhvatan program i servise za poticanje ranog dječjeg razvoja na razini lokalne zajednice (http://eclkc.ohs.acf.hhs.gov/hslc/tta-system/ehsnrc/about-ehs). 
prakse roditeljstva te ulaganjem u obiteljsko okruženje može se postići potreban kumulativni efekt ranointerventnih programa namijenjenih reduciranju rizika ili pak jačanju otpornosti djece i njihovih obitelji (Ferić, 2002).

\section{PERSPEKTIVA ROMSKOG DJETETA}

Danas su nam dostupni vrlo vrijedni podaci nekoliko sveobuhvatnih nacionalnih istraživanja koja popunjavaju prazninu i neusklađenost službenih statističkih pokazatelja položaja romske nacionalne manjine (Štambuk, 2005; Brajša-Žganec i sur., 2011; UNDP Hrvatska, 2015; Šikić-Mićanović i sur., 2015; Šućur i sur., 2015). Nažalost, sva istraživanja ukazuju na marginaliziran i višestruko depriviran položaj Roma, a posebno razotkrivaju status romske djece kao jedne od najranjivijih skupina djece. Gotovo svi Romi (92,3\%) žive u relativnom siromaštvu, a 9\% njih (u odnosu na 5,5\% ostalog stanovništva) živi u apsolutnom siromaštvu (UNDP Hrvatska, 2015). Implikacije koje život i odrastanje u takvim uvjetima ima na djecu su razorne imajući pri tom na umu da djeca proživljavaju siromaštvo na drugačiji način od odraslih zbog njihove veće ranjivosti i ovisničkog položaja (Šućur i sur., 2015), ali i činjenice da žrvanj siromaštva pogađa djecu već i u predporođajnom razdoblju kroz kvalitetu života majke djeteta (Vasta i sur., 1998).

U UNICEF-ovom istraživanju siromaštva predškolske djece (Šućur i sur., 2015) kao najranjivija skupina pokazala se skupina predškolske djece čije su obitelji korisnici socijalne pomoći, a unutar te kategorije posebno podskupine djece $\mathrm{s}$ teškoćama u razvoju i djeca romske nacionalne manjine. $U$ te dvije podskupine djece primjetna je raširenija prisutnost apsolutnog i ekstremnog siromaštva u odnosu na ukupni uzorak siromašne djece. Uzimajući u obzir pokazatelje materijalne deprivacije (prehrambene navike, dostupnost odjeće, obuće i edukativnih materijala, siguran prostor za igru, odgovarajuća medicinska skrb), na većini pokazatelja deprivirano je više od $40 \%$ romske predškolske djece. $1 / 3$ djece $(61 \%)$ romske nacionalne manjine ne posjeduje niti jednu slikovnicu ili knjigu kod kuće, a $2 / 3$ roditelja ne može svom djetetu priuštiti neku vrstu edukativne igračke. Majke pripadnice romske nacionalne manjine najmanje su uključene u aktivnosti čitanja slikovnica ili knjiga za djecu, pričanja priča, pjevanja pjesmica, igranja s djetetom ili učenja djeteta osnovnim pojmovima što bi se moglo pripisati i nedostatku osnovnih vještina čitanja uslijed njihove niske ili gotovo nikakve izobrazbe. Navedeni nalaz sugerira kako problem nije samo u nedostatku novca već i u određenim karakteristikama roditelja koje nepovoljno utječu na dječji razvoj. Poznato je da su siromašniji roditelji u pravilu slabije obrazovani i često nižih kapaciteta za stvaranje okoline koja biti trebala biti intelektualno poticajna za dijete. Optimizam u ovakvu sliku svakodnevnice djece Roma unose već prije istaknuti nalazi koji sugeriraju da provođenjem programa podrške roditeljstvu kao što su treninzi roditeljskih vještina, podučavanje roditelja strategijama nošenja sa stresom kao i podučavanje roditelja konkretnim vještinama za poticanje kognitivnog, jezičnog i socio-emocionalnog razvoja djeteta osnažuju roditelje $u$ ispunjavanju zahtjeva roditeljske uloge (Ferić, 2002; Pećnik, 2013).

Nadalje, činjenica koja se vrlo često previđa i zanemaruje je da romskoj djeci prvi jezik nije hrvatski jezik. Kada se kumulativnom učinku niskog SES statusa obitelji pridoda i jezična barijera koja se često spominje u kontekstu procjene spremnosti za upis u školu, onda hitnost usmjeravanja fokusa na sveobuhvatne i ranointerventne programe još više dolazi do izražaja. Nažalost, pokazalo se da obuhvat romske djece vrtićkim i predškolskim programima i dalje predstavlja izazov. Odgovornost za dostupnost usluga predškolskog odgoja i obrazovanja djece od 0-6 godina spuštena je na razinu lokalnih zajednica koje se često razlikuju u svojim kapacitetima, ali i prioritetima. Navedeno se reflektira na način da je pristup uslugama i resursima za djecu rane dobi (pa tako i one romske nacionalne manjine) uvjetovan mjestom stanovanja (Pećnik, 2013; Šikić-Mićinović, 2015). Stoga i ne čudi podatak iz RECI+ istraživanja (Šikić-Mićinović, 2015) da je tek 20\% romske djece u dobi između 0 i 6 godina bilo obuhvaćeno nekim oblikom predškolskog odgoja. Ipak, odlukom Ministarstva znanosti, obrazovanja i sporta kojom od listopada 2014. za svu djecu koja nisu obuhvaćena redovitim programom predškole u dječjem vrtiću postaje obvezno pohađanje programa predškolskog odgoja u godini dana prije polaska u osnovnu školu može se očekivati i povećan obuhvat djece rom- 
ske nacionalne manjine takvim uslugama (Zakon o predškolskom odgoju i obrazovanju, NN 94/13). Pod pretpostavkom povećanja obuhvata romske djece predškolskim programima slijedi nužnost osiguravanja kvalitete tih programa koji će moći ublažiti učinke osiromašenog i rizičnog okruženja s ciljem izjednačavanja startnih pozicija romske djece pri uključivanju u osnovnu školu. Vrijednu polazišnu točku u tom kontekstu predstavlja i Test za poznavanje hrvatskog jezika za upis $u$ 1. razred osnovne škole za djecu osnovne škole koja ne znaju ili nedovoljno znaju hrvatski jezik u izdanju Nacionalnog centra za vanjsko vrednovanje pod autorstvom stručnjaka Edukacijsko-rehabilitacijskog fakulteta i Učiteljskog fakulteta Sveučilišta u Zagrebu (http:// ncvvo.hr, prosinac 2015).

\section{AKTIVNOSTI I PROGRAMI USMJERENI OSNAŽIVANJU NEPISMENIH RODITELJA}

Unatoč skromnosti primjera o načinima uključivanja nepismenih roditelja, možemo se osloniti na prijedloge nekih autora o praktičnim tehnikama koje roditelji mogu naučiti kako bi podržali svoju u djecu u jezično-govornom razvoju. Cooter (2006, prema Menheere i Hooge, 2010) smatra da učitelji mogu naučiti roditelje različitim tehnikama čitanja kao što je npr. dijaloško čitanje. Tijekom dijaloškog čitanja dijete vodi razgovor vezan uz slike ili sadržaj knjige, a roditelj sluša, postavlja pitanja, redefinira dječje izjave i proširuje razgovor. Učitelji mogu podučiti roditelje kako koristiti slikovnice i igračke te kako poticajnim pitanjima usmjeravati dijete na upotrebu što većeg broja riječi i izražavanja punim rečenicama. Učitelji kao modeli mogu pokazati roditeljima kako se stvara poticajno okruženje za djecu, na koji način odabrati knjige za djecu te poticati i pomoći roditeljima da unaprijede vlastite vještine čitanja i pisanja.

Farris i Denner (1991) predlažu sljedeće strategije u pružanju podrške nepismenim roditeljima i njihovoj djeci:

- sastanci i radionice s roditeljima - takvi susreti s roditeljima moraju biti brižljivo planirani i provedeni kako se nepismene roditelje ne bi dodatno stigmatiziralo. Osim podučavanja roditelja različitim tehnikama čitanja i načinima poticanja rane pismenosti, na sastancima se mora promovirati vrijednost čitanja kako bi se smanjio rizik od nedolaska na takve susrete i kako bi se roditelje motiviralo da održe kontinuitet u pružanju podrške svom djetetu.

- poticanje pričanja priča - budući da nepismeni roditelji često mogu biti zastrašeni knjigama koje teško čitaju ili ih ne mogu čitati, roditelje se može poticati da pričaju priče svojoj djeci. To mogu biti bajke, ali ako roditelji nisu upoznati s njima posebno su vrijedne obiteljske priče ili priče koje sami izmišljaju. Uz to roditeljima se mogu ponuditi slikovnice koje ne sadrže pisani tekst već samo slike koje će služiti kao poticaj ili vodič za pričanje priče.

- knjižnica u učionici - budući da su nepismeni roditelji rjeđe članovi knjižnice ili su im one nedostupne ili pak im je nedostupna literatura na njihovom materinskom jeziku, vrlo je korisno stvoriti knjižnicu u učionici koja će biti opremljena velikim brojem kvalitetnih dječjih knjiga koje će roditelji moći posuđivati za čitanje s djecom kod kuće.

- vizualni "popis" dječjih knjiga - umjesto klasičnog popisa dječjih knjiga i slikovnica, roditeljima se mogu pripremiti fotokopije naslovnih strana knjiga ili uručak s fotografijama knjiga. Takav materijal služi kao vizualna pomoć koja ne zahtijeva čitanje, a omogućuje roditelju da lakše pronađe knjigu ili je prepozna npr. u knjižnici ili dućanu.

- edukativne slikovnice - roditeljima se mogu predložiti slikovnice koje opisuju jednostavne znanstvene i društvene koncepte npr. iz područja matematike, događanja i promjena u prirodi, kvalitete prehrane, međuljudskog ophođenja, glazbe i sl.

- kućne posjete - tijekom kućnih posjeta osim boljeg međusobnog poznavanja i razumijevanja, učitelji mogu poslužiti kao model i poticati zajedničko čitanje kako bi roditelji kasnije mogli na isti način čitati s djecom. Osim knjiga, roditeljima se mogu pokloniti ili posuditi različite igračke ili materijali od kojih mogu sami napraviti igračke sa svojom djecom (kuti- 
je od jaja, vuna, drvo, čepovi, papirnate vrećice, tkanina i sl.) ili materijal za pisanje.

U nastavku slijedi kratki prikaz programa namijenjenih djeci predškolske i rane školske dobi i njihovim roditeljima iz nižeg SES statusa koji potiču razvoj pismenosti i drugih kognitivnih vještina kod djece te osnažuju roditelje za ispunjavanje zahtjeva roditeljske uloge. Iako se radi o ranointerventnim programima, odnosno, programima koji obuhvaćaju djecu u vrlo ranoj dobi ili prije polaska u školu, takav sustav intervencija počiva na ideji stvaranja kontinuuma $\mathrm{u}$ ponudi usluga $\mathrm{u}$ zajednici i povezivanja predškolskog i osnovnoškolskog sustava. Stoga su opisani programi izdvojeni na temelju procijenjenih mogućnosti njihove implementacije u školskom okruženju i lokalnim zajednicama.

Naziv programa: $M O C E P$ - The Mother-Child Home Education Programme

\section{Zemlja: Bahrain}

Osnovne informacije: Program traje 6 mjeseci i sastoji se od dvije komponente: (1) program podrške majkama i (2) poticanje kognitivnog razvoja kod djece. Podrška majkama osigurava se kroz jačanje njihovih vještina čitanja i pisanja kroz tjedne susrete na kojima se raspravlja i o različitim temama vezanima uz dječji razvoj (discipliniranje, zdravlje i sigurnost, prehrana, planirano roditeljstvo i komunikacijske vještine). Sudionice dobivaju paket edukativnih materijala koje koriste s djecom za poticanje njihovog kognitivnog razvoja. U tome im pomaže dodijeljeni obiteljski mentor koji na tjednoj razini posjećuje obitelj i podučava majke kako pristupiti vlastitom djetetu. Voditelji radionica prolaze intenzivnu jednogodišnju edukaciju, a nužni uvjet je da i sami budu bilingualni, tj. da govore i engleski i arapski.

\section{Naziv programa: Meséd-Mother Telling Stories}

\section{Zemlja: Mađarska}

Osnovne informacije: Program traje 3 mjeseca, a radionice se održavaju jednom tjedno. Ciljana skupina su djeca i majke romske nacionalne manjine, posebno slabije obrazovane majke koje su prerano ispale iz sustava obrazovanja. U malim grupama majke se podučava i potiče da svojoj djeci na glas čitaju priče i slikovnice. Svaka pročitana priča razma- tra se iz perspektive njezine poruke i načina na koji majke mogu ciljano iskoristiti priču za socio-emocionalni razvoj djeteta. Osim podučavanju tehnikama čitanja, na radionicama se raspravlja o odgojnim temama.

Naziv programa: $R E F$-ove biblioteke igračaka u Srbiji

\section{Zemlja: Srbija}

Osnovne informacije: Program se provodi u sklopu projekta Za majku i dijete Obrazovnokulturne zajednice Romanipen na 5 različitih lokacija u Srbiji. Djeca i njihovi roditelji mogu svakodnevno dolaziti u knjižnicu igračaka opremljenu kvalitetnim edukativnim materijalom, dječjim knjigama i igračkama, a igračke koje se im se najviše svide mogu posuditi i ponijeti kući. Za vrijeme dok asistenti rade s djecom, za roditelje se organiziraju radionice različite tematike, između ostalog i radionice u suradnji s domovima zdravlja, radionice opismenjavanja roditelja, odgojno savjetovalište i sl. Za korisnike je osiguran besplatan prijevoz na radionice, a za one obitelji koje ne mogu redovito dolaziti organizirana je mobilna knjižnica igračaka.

\section{Naziv programa: Poticajno roditeljstvo}

\section{Zemlja: Hrvatska}

Osnovne informacije: Program se počeo provoditi u sklopu projekta Osnaživanje roditelja romske nacionalnosti za podršku razvoju i učenju njihove djece Pučkog otvorenog učilišta Korak po korak. Uz prethodnu edukaciju učitelji, stručni suradnici, odgajatelji i romski pomagači provode radionice s roditeljima i članovima obitelji djece jednom tjedno $\mathrm{u}$ školi u godini prije upisa djece u prvi razred. $\mathrm{Na}$ radionicama zajedno sudjeluju djeca i roditelji. $\mathrm{Na}$ svakoj radionici radi se s materijalima koji potiču razvoj predvještina čitanja i pisanja te matematičkih vještina kod djece, a s tim materijalima roditelji nastavljaju raditi s djecom kod kuće.

\section{AKTIVNOSTI ŠKOLE U PIŠKOROVCU}

Nakon obitelji škola je najvažnije djetetovo okruženje i s aspekta njezinog doprinosa u pružanju podrške zdravom razvoju djeteta nezaobila- 
Tablica 1. Varijable anketnog upitnika

\begin{tabular}{|l|l|}
\hline Podaci na razini kućanstva & Podaci za svakog pojedinog ispitanika \\
\hline - tip kućanstva (s djecom, bez djece, samačko & - ime i prezime* \\
kućanstvo) & - uloga, tj. odnos s djetetom (majka, otac, baka,djed, zakonski skrbnik) \\
- ukupan broj osoba koje žive u kući & - životna dob \\
- broj punoljetnih osoba u kući & - polaženje redovne osnovne i/ili srednje škole \\
- broj djece prema uzrastu po skupinama: 0-5 & $\begin{array}{l}\text { - godine školovanja u redovnoj osnovnoj i/ili srednjoj školi } \\
\text { god, 6-10 god, 11-15 god }\end{array}$ \\
& - školovanje preko tečajeva i završeni stupanj osnovne/srednje škole \\
& - razina pismenosti u odnosu na vještinu pisanja \\
& - razina pismenosti u odnosu na vještinu čitanja i razumijevanja pročitanog \\
& - vrsta rada \\
& - zaposlenost s ugovorom/bez ugovora \\
& zainteresiranost za uključivanje u program opismenjavanja \\
\hline
\end{tabular}

*Ime i prezime ispitanika prikupljalo se isključivo s ciljem lakšeg identificiranja potencijalnih korisnika programa opismenjavanja,a svakom ispitaniku garantirana je anonimnost u obradi i prezentiranju rezultata.

zna je suradnja tih dviju sredina. Ni jedan od ovih čimbenika ne može u potpunosti pridonijeti unapređivanju dječjeg razvoja ako ne vodi računa o mogućnostima i utjecaju one druge strane (Maleš, 2003.). Kada su u pitanju djeca iz depriviranih sredina - u ovom slučaju djeca romske nacionalne manjine, uloga, moć i odgovornost škole još više dobiva na važnosti. U tom smislu, podršku koju škola pruža učenicima romske nacionalne manjine možemo sagledavati kroz razinu kvalitete nastave i odgojno-obrazovnog procesa koja je u školi neposredno dostupna učenicima romske nacionalne manjine, ali i kroz proaktivnost u iznalaženju posrednih načina kompenzacije negativnih učinaka izrazito osiromašenog okruženja u kojima učenici Romi odrastaju. Uključivanje, suradnja i osnaživanje roditelja u tom kontekstu je od krucijalne važnosti pri čemu je potrebno istaknuti da modaliteti uključivanja Romskih roditelja često zahtijevaju promišljanje izvan okvira klasičnih oblika suradnje škole i obitelji.

Osnovnu školu Tomaša Goričanca Mala Subotica - Područnu školu Držimurec-Strelec unatrag dvije godine pohađaju samo učenici romske nacionalne manjine. Kao zaposlenici škole (učitelji i romski pomagači) i članovi zagovaračke mreže za potporu romskoj djeci REYN - Hrvatska ${ }^{3}$, a potaknuti vlastitim iskustvom neposrednog rada $\mathrm{s}$ nepismenim roditelji- ma i njihovom djecom te željom za poduzimanjem konkretnih aktivnosti koje će utjecati na uspješnost učenika u obrazovanju, osmislili smo vlastitu lokalnu zagovaračku akciju u kojoj je procjena potreba u obliku terenskog istraživanja činila prvi korak. Osnovni cilj istraživanja je bio utvrditi obrazovnu strukturu i razinu pismenosti odraslog stanovništva naselja Piškorovec kako bi se na temelju dobivenih rezultata mogao planirati program intervencije koji će biti temeljen na procijenjenim potrebama. Posebni ciljevi istraživanja bili su dobiti detaljniji uvid u demografske karakteristike podskupine nepismenih odraslih osoba u Piškorovcu te broj djece koja žive s nepismenim roditeljima. Istraživanje je provedeno u romskom naselju Piškorovec u prosincu 2014. Posebnu vrijednost provedbi istraživanja dala je i ostvarena suradnja između škole i romske zajednice prije, tijekom i nakon provedenog istraživanja. Rezultati istraživanja su predstavljeni samim ispitanicima u svibnju 2015. Za potrebe istraživanja učitelji su sami osmislili instrumentarij - anketni upitnik koji je korišten u istraživanju. Upitnikom su prikupljani opći podaci na razini kućanstva te specifični podaci za svakog pojedinog ispitanika. Podaci koji su se prikupljali prikazani su u Tablici 1.

Upitnik je konstruiran na način da u sebi sadrži dijelove kojima se tijekom razgovora s ispitanikom

3 Mreža podrške romskoj djeci REYN-Hrvatska (Romani Early Years Network) je zajednica učenja i zagovaračka mreža profesionalaca, paraprofesionalaca, institucija, nevladinih i drugih organizacija i pojedinaca u području odgoja i obrazovanja romske djece. Djeluje sa svrhom pružanja podrške odraslima, kako bi i sami mogli podržati romsku djecu u ostvarivanju jednakih prava na pristup kvalitetnom odgoju i obrazovanju, poticajnom okruženju za razvoj i učenje te mogućnosti da budu uspješna u svojim životima (http://reyn-hrvatska.net). 
Maja Kutnjak: Aktivnosti usmjerene osnaživanju nepismenih roditelja romske djece

Tablica 2. Kategorije utvrđivanja pismenosti s obzirom na usvojenost vještina čitanja i pisanja

\begin{tabular}{|l|l|l|}
\hline Kategorije usvojenosti vještina & Čitanje & Pisanje \\
\hline Razina 1 & ne poznaje slova, ne čita & $\begin{array}{l}\text { ne piše (potpuno nepismen ili se zna samo } \\
\text { potpisati) }\end{array}$ \\
\hline Razina 2 & $\begin{array}{l}\text { Poznaje velika i mala tiskana slova i čita } \\
\text { slovkanjem kraće riječi, razumije pročitano }\end{array}$ & $\begin{array}{l}\text { piše velikim ili malim tiskanim ili pisanim } \\
\text { slovima, kraće riječi }\end{array}$ \\
\hline Razina 3 & čita s razumijevanjem & piše tiskanim i pisanim slovima \\
\hline
\end{tabular}

neposredno provjeravala razina usvojenosti čitanja i pisanja. Od ispitanika se tražilo da:

1. pročitaju jednostavan tekst napisan velikim i malim tiskanim slovima te da ukratko prepričaju što su pročitali ili da odgovore na pitanje ispitivača vezano uz tekst

2. prepišu napisanu rečenicu velikim tiskanim $i$ malim pisanim slovima

3. bez pomoći ispitivača pismeno odgovore na postavljeno pitanje ako je prethodno utvrđeno da ispitanik/ica zna čitati i pisati (primjer pitanja: "Napišite ime svog najmlađeg djeteta" $\mathrm{i}$ "Koji je danas dan")

4. napišu rečenicu po diktatu koju ispitanici sami odabiru govoreći broj rečenice od 1 do 40 (kao sastavni dio upitnika kreirana je Lista rečenica. Rečenice su se sastojale od 5-7 riječi, a sadržajno su se odnosile na pojave, stvari i događaje iz svakodnevnog života. Primjer rečenica: "Moja kćer je završila srednju školu”, "Jedna godina ima dvanaest mjeseci". Pri tome se ostavljalo na izbor ispitaniku/ici kakvom vrstom slova će pisati pri davanju odgovora).

Utvrđena razina pismenosti ispitanika (s aspekta usvojenosti vještina čitanja, odnosno, razumijevanja pročitanog i usvojenosti vještina pisanja) svrstavala se u tri kategorije:

Kriterij pri formuliranju kategorije bio je isključivo praktične naravi: ekstrahirati ispitanike u ulozi roditelja koji su potpuno nepismeni ili su njihove vještine čitanja i pisanja slabo razvijene (Razine 1 i 2) kako bi se identificiralo skupinu koja ima najveću potrebu za uključivanjem u program opismenjavanja.

U istraživanju je sudjelovalo ukupno 212 osoba, od čega 105 muških i 107 ženskih osoba. Tih 212 ispitanih osoba ukupno ima 345 djece u dobi 0-15 godina. Dobiveno je da je prosječan broj djece u kućanstvu 4,42.

Deskriptivnom analizom prikupljenih podataka utvrđeno je da:

- jedna četvrtina ispitanika (50 osoba) nikad nije pohađala osnovnu školu niti bila uključena u bilo koji drugi oblik obrazovanja. Dodamo li tome brojku od 108 ispitanika (51\%) koji su polazili redovnu osnovnu školu, ali su ispali iz sustava dolazimo do dvije trećine, tj. 75\% ispitnika (a slobodno možemo reći odraslih stanovnika Piškorovca) nema završenu osnovnu školu

- prosječni broj završenih razreda onih koji su pohađali osnovnu školu je 4 razreda osnovne škole

- 39 ispitanika (svaki peti) je uspješno završio osnovnu školu, a 15 ispitanika (svaki četrnaesti) uspješno je završilo srednju školu u redovnom ili van redovnog sustava

- u svim promatranim varijablama više je nego očita neravnomjernost $\mathrm{s}$ obzirom na spol $\mathrm{u}$ korist muškaraca: žene su slabije obrazovane, kada su i uključene u prosjeku završavaju manje razreda i u manjem broju u odnosu na muškarce do kraja završavaju obrazovni proces (posebice srednju školu)

- 65 ispitanika $(30,6 \%)$ je potpuno nepismeno ${ }^{4}$

- tek polovica ispitanika (11 osoba, odnosno $52,35 \%$ ) je funkcionalno pismena (razina 3 )

- uz 65 potpuno nepismenih osoba još 23 osobe iskazuju potrebu za dodatnim ulaganjem u učenje vještina čitanja i pisanja (razina 2)

- $63 \%$ potpuno nepismenih osoba $(\mathrm{N}=41)$ sačinjavaju žene (uglavnom majke)

- najveći broj potpuno nepismenih osoba nalazi se u dobnoj skupini 31-35 godina (15

4 Za usporedbu, postotak nepismenih osoba na razini Republike Hrvatske kreće se između 1 i $2 \%$ (2001. u Hrvatskoj je bilo 1,77\% nepismenih osoba, a prema zadnjem popisu stanovništva 2011. taj postotak iznosi 0,8\%, izvor: Državni zavod za statistiku). 
osoba) što se poklapa sa skupinom koja ima najviše djece

- u dobi 18-40 godina nepismeno je 25 žena. Uzmemo li u obzir prosječan broj djece po kućanstvu (4,42 djece) 110 djece (jedna trećina, tj. 28\%) živi s nepismenom majkom

- radno aktivno je $27,35 \%$ ispitanika, od čega $86,2 \%$ u sivoj ekonomiji (povremeni poslovi bez ugovora)

- od ukupnog broj ispitanika, 50 je zainteresiranih za uključivanje u program opismenjavanja ako bi se provodio u školi (od toga 40 njih potpuno nepismenih)

Ovo istraživanje ima i svoje praktične implikacije. Provedenim istraživanjem identificirana je skupina nepismenih osoba u ulozi roditelja koja iskazuje najveću potrebu za uključivanjem u program opismenjavanja što je bila i svrha istraživanja. U praksi i u literaturi nailazi se na ograničen broj istraživanja i primjera o uključivanju nepismenih roditelja (nasuprot opsežnoj literaturi o važnosti i generalnim načinima uključivanja roditelja u odgoj i obrazovanje djece te partnerstvo sa školom).

Polazeći od rezultata istraživanja te uzimajući u obzir dosadašnje iskustvo u radu s djecom i roditeljima romske nacionalne manjine, učitelji i romski pomagači osmislili su plan programa opismenjavanja roditelja koji je uobličen u projektni prijedlog pod nazivom "Razvoj i implementacija programa opismenjavanja roditelja u naselju Piškorovec" i apliciran na Roma Education Fund. Projekt je osmišljen u partnerstvu s Međimurskom županijom, Općinom Mala Subotica i Pučkim otvorenim učilištem Korak po korak. Cilj projekta je razvoj poticajnog okruženja za djecu kroz osnaživanje roditeljskih vještina čitanja i pisanja. Sam program opismenjavanja roditelja zamišljen je u 2 dijela: 40 radionica u trajanju od 2 sata na kojima će se roditelje učiti čitati i pisati te 10 zajedničkih radionica djece i roditelja na kojima će se roditelje podučavati vještinama za poticanje dječjeg jezično-govornog razvoja ali i za stvaranje kvalitetnog odnosa i privrženosti s njihovom djecom kroz korištenje i stvaranje vlastitih edukativnih materijala (čitanje priča i slikovnica, izrađivanje zajedničkih slikovnica,...). Osnovna svrha je osnažiti roditelje za stvaranje poticajnog okruženja za učenje za njihovu djecu kod kuće. Radionice s roditeljima i dje- com provodili bi učitelji razredne nastave, romski pomagači i stručni suradnici zaposleni u školi što smatramo posebno važnim u kontekstu osnaživanja škole za razvoj suradnje s roditeljima i stvaranjem kvalitetnog odnosa s njima. Drugi aspekt projektnog prijedloga je razvoj i jačanje partnerstva u lokalnoj zajednici. Kao što je već navedeno, provedeno istraživanje je prvi dio lokalne zagovaračke akcije koju smo osmislili. Implementacija programa opismenjavanja je, uz prethodno osiguravanje financijskih sredstava, sljedeći korak. Dakle, naša intencija je razviti model rada na razini lokalne zajednice kroz linearne korake koji će biti dovoljno strukturiran ali i dovoljno fleksibilan da se može prilagoditi potrebama i specifičnostima svake pojedine lokalne zajednice. Taj model rada počinje već od same motivacije ispitanika za sudjelovanje u istraživanju, identificiranja konkretnih osoba i populacijske skupine koja ima potrebu za uključivanjem u program opismenjavanja, predstavljanja rezultata samim ispitanicima i konačno do motivacije potencijalnih korisnika programa opismenjavanja za redovito sudjelovanje u programu. U trenutku pisanja ovog rada čeka se povratna informacija donatora o prihvatljivosti projektnog prijedloga.

\section{ZAKLJUČAK}

Činjenicu da razvoj djeteta i njegov napredak ovise o jedinstvenom međudjelovanju djetetovih karakteristika i karakteristika njegove okoline posebno je zanimljivo i vrijedno promatrati iz perspektive mogućnosti preventivnog djelovanja s ciljem pružanja pravovremene i adekvatne podrške djetetu za optimalan i zdrav razvoj. Djeci koja odrastaju u nepovoljnom obiteljskom okruženju adekvatna podrška ranom kognitivnom i govornojezičnom razvoju često je nedostupna, što se povezuje s niskom obrazovanošću roditelja i životom u siromaštvu te $\mathrm{s}$ karakteristikama roditelja proizašlih iz kombinacije tih čimbenika. Tu se posebno izdvajaju djeca romske nacionalne manjine koja češće od ostalih žive s roditeljima koji su nepismeni ili vrlo nisko obrazovani i ekstremno siromašni. S obzirom da je sustav ponude ranointerventnih i drugih kompenzacijskih programa u Hrvatskoj još uvijek slaba karika, škole su često primorane same pronalaziti načine kojima će ublažiti poslje- 
dice osiromašenog i nestimulativnog okruženja u kojima učenici Romi odrastaju. U ovom radu predstavljen je jedan od načina na koji škola može izaći iz okvira klasičnih oblika suradnje s roditeljima i pripremiti temelj za planiranje programa koje će implementirati na temelju procijenjenih potreba, a sve s ciljem osnaživanja i "opremanja" roditelja potrebnim vještinama za pružanje podrške u kognitivnom i jezično-govornom razvoju svojeg djeteta. Istraživanje koje su proveli učitelji i romski pomagači u romskom naselju Piškorovec poklapa se $\mathrm{s}$ istraživanjima na nacionalnoj razini koja ukazuju na marginaliziranost romske populacije i osvjetljavaju razmjere depriviranosti okruženja u kojem odrastaju djeca. Podatak da je od uku- pno 212 ispitanih osoba njih $63(30,6 \%)$ potpuno nepismeno i činjenica da 110 djece u Piškorovcu u dobi od 0-14 godina živi s nepismenom majkom je alarm koji ne ostavlja luksuz zakašnjelih reakcija i krivo postavljenih prioriteta te upućuje na nužnost poduzimanja intervencija koje će biti usmjerene i na djecu i na roditelje. Škole posjeduju stručne kapacitete te ljudske i materijalne resurse koje je potrebno mobilizirati i iskoristiti u planiranju i implementaciji programa podrške romskim roditeljima. Opismenjavanje roditelja je izazovan ali potreban poduhvat ako se želi sagraditi temelje na kojima se kasnije mogu nadograđivati i druge vještine kojima će roditelji moći pružiti podršku svom djetetu tijekom njegovog obrazovanja. 


\section{LITERATURA:}

Babarović, T., Burušić, J., Šakić, M. (2010): Psihosocijalne i obrazovne odrednice školskog uspjeha učenika osnovnih škola: dosezi dosadašnjih istraživanja. Suvremena psihologija, 13, 2, 235-256.

Bašić, J. (2009): Teorije prevencije: prevencija poremećaja u ponašanju i rizičnih ponašanja djece i mladih. Zagreb: Školska knjiga.

Bedeniković Lež, M. (2009): Uloga majke u školskom uspjehu. Školski vjesnik, 58,3, 331-344.

Brajša-Žganec, A., Franc, R., Merkaš, M., Radačić, I., Šerić, M., Šikić-Mićanović, L. (2011): Analiza stanja prava djece i žena u Hrvatskoj. Zagreb: UNICEF Hrvatska.

Burušić, J., Babarović, T., Marković, N. (2010): Koliko daleko padaju jabuke od stable? Odnos obrazovnih postignuća djece i obrazovne razine roditelja. Društvena istraživanja, 19, 4-5, 709-730.

Bus, A.G., van IJzendoorn, M.H., Pellegrini, A.D. (1995): Joint book reading makes for success in learning to read: a meta-analysis on intergenerational transmission of literacy. Review of Educational Research, 65, 1-21.

Carrol, C. J. (2013): The Effects of Parental Literacy Involvement and Child Reading Interest on the Development of Emergent Literacy Skills.Theses and Dissertation. (preuzeto sa: http://dc.uwm.edu/etd/230/, srpanj 2015).

Davis-Keane, P. E. (2005): The Influence of Parent Education and Family Income on Child

Achievement: The Indirect Role of Parental Expectations and the Home Environment. Journal of Family Psychology, 19,2, 294-304.

Engle, P. L., Black M. M. (2008): The Effect of Poverty on Child Development and Educational Outcomes. Annals of the New York Academy of Sciences, 1136, 243-256. (preuzeto sa: http://digitalcommons.calpoly.edu/cgi/ viewcontent.cgi?article $=1002 \&$ context=psycd_fac; srpanj 2015).

Farris, P. J., Denner, M. (1991): Guiding Illiterate Parents in Assisting Their Children in Emergent Literacy. Reading Horizons, 32,1, 63-72.

Fekonja-Peklaj, U., Marjanovič-Umek, Lj. (2011): Familiy literacy environment and parental education in relation to different measures of child's language. Suvremena psihologija, 14,1,57-73.

Ferić, M. (2002): Preventivne intervencije usmjerene prema obitelji-pregled programa. Kriminologija i socijalna integracija, 10,1,1-12.

Ferić, I., Milas, G., Rihtar, S. (2010): Razlozi i odrednice ranog napuštanja školovanja. Društvena istraživanja, 19, 4-5, 621-642.

Gregurović, M., Kuti, S. (2010.): Učinak socioekonomskog statusa na obrazovno postignuće učenika: Primjer PISA istraživanja, Hrvatska 2006. Revija za socijalnu politiku, 17, 2, 179-196.

Grginič, M. (2007): Što petogodišnjaci znaju o pismenosti. Život i škola, 17,1, 7-27.

Hoff, E. (2003): The Specificity of Environmental Influence: Socioeconomic Status Affects Early Vocabulary Development Via Maternal Speech. Child Development, 74,5,1368-1378.

Jerrim, J., Micklewright, J. (2011): Children's cognitive ability and parents' education: distinguishing the impact of mothers and fathers. (preuzeto sa: https://johnjerrim.files.wordpress.com/2013/07/jj_jm_madison_jan_26_2011_ rsf.pdf; posjećeno u kolovozu 2015).

Jokić, B., Ristić Dedić, Z. (2010): Razlike u školskom uspjehu učenika trećih i sedmih razreda osnovnih škola u Republici Hrvatskoj s obzirom na spol učenika i obrazovanje roditelja: populacijska perspektiva. Revija za socijalnu politiku, 17,3, 345-362.

Kranželić Tavra, V., Bašić, J. (2005): Školski neuspjeh i napuštanje škole. Dijete i društvo, 7,1, 15-28.

Leseman, P.M., de Jong, P.F. (1998): Home literacy: Opportunity, instruction, cooperation and socialemotional quality predicting early reading achievement. Reading Research Quarterly, 33,3, 294-318. 
Lyytinen, P., Laasko, M., \& Poikkeus, A. (1998). Parental contributions to child's early language and interest in books. European Journal of Psychology of Education, 13, 297-308.

Maleš, D. (2003): Suradnja škole, obitelji i lokalne zajednice u prevenciji poremećaja u ponašnju djece i mladih. U: Bašić, J., Janković. J., (ur): Lokalna zajednica - izvorište Nacionalne strategije prevencije poremećaja u ponašanju. Zagreb: Državni zavod za zaštitu obitelji, materinstva i mladeži - Povjerenstvo Vlade Republike Hrvatske za prevenciju poremećaja u ponašanju, 84-103.

Matković, T. (2009): Obrazovanje roditelja, materijalni status i rano napuštanje školovanja u Hrvatskoj: trendovi u proteklom desetljeću. Društvena istraživanja, 19, 4-5, 643-667.

Menheere, A., Hooge, H.E. (2010): Parental involvement in childrens' education: A review study about the effect of parental involvement on children's school education with a focus on the position of illiterate parents. Journal of the European Teacher Education Network JETEN, 6, 144-157.

Pećnik, N. (2013): Kako roditelji i zajednice brinu o djeci najmlađe dobi u Hrvatskoj. Zagreb: UNICEF.

Raikes, H., Pan, B. A., Luze, G., Tamis-LeMonda, C. S., Brooks-Gunn (2006): Mother-Child Bookreading in LowIncome Families: Correlates and Outcomes During the First Three Years of Life. Child Development, 77,4, 924-953.

Rosenthal, B. S. (1998): Non-school correlates of dropout: An integrative review of the literature. Children and Youth Services Review, 20: 413-433.

Rowe, M. L. (2008): Child-directed speech: relation to socioeconomic status, knowledge of child development and child vocabulary skill. Journal of Child Language, 35, 185-205.

Sénéchal, M., LeFevre, J., Thomas, E., Daley, K. (1998): Differential effects of home literacy experiences on the development of oral and written language. Reading Research Quarterly, 32,1, 96-116.

Silvén, M., Ahtola, A., Niemi, P. (2003): Early words, multiword utterances and maternal reading strategies as predictors of mastering word inflections in Finnish. Journal of Child Language, 30, 253-279.

Stričević, I. (2007): Rana pismenost u kontekstu ključnih kompetencija za cjeloživotno učenje. Dijete i društvo, 9,1, 49-59.

Šikić-Mićanović, L., Ivatts, A. R., Vojak, D., Geiger-Zeman, M. (2015): Socijalno uključivanje djece Roma (RECI+). Izvještaj za Hrvatsku. Zagreb: Pučko otvoreno učilište Korak po korak.

Štambuk, M. (2005): Obilježja romskih obitelji - kućanstava. u: Kako žive hrvatski Romi. Ur. Maja Štambuk. Zagreb: Institut društvenih znanost Ivo Pilar

Šućur, Z., Kletečki Radović, M., Družić Ljubotina, O., Babić, Z. (2015): Siromaštvo i dobrobit djece predškolske dobi u Republici Hrvatskoj. Zgreb: UNICEF. (preuzeto sa: http://www.unicef.hr/show.jsp?newscontainer=2010 43\&page=146930\&singlenewsid=201117; posjećeno u srpanju 2015).

Trikić, Z. (2012): Building Opportunities in Early Childhood from the Start: A Teacher's Guide to Good Practices in Inclusive Early Childhood Services. Budapest: Roma Education Fund.

UNESCO (2005). Aspects of Literacy Assessment: Topics and issues from the UNESCO Expert Meeting, 10-12 June 2003. Paris, UNESCO (preuzeto sa: http://unesdoc.unesco.org/images/0014/001401/140125eo.pdf, posjećeno u studenom 2014).

UNDP Hrvatska (2013): Atlas romskih naselja Međimurske županije (preuzeto sa: http://www.hr.undp.org/content/dam/ croatia/docs/Research\%20and\%20publications/socialinclusion/UNDP-HR-ATLAS-ROMA-MEDJIMURJE-2014. pdf; posjećeno u studenom 2014).

UNDP Hrvatska (2015): Romska svakodnevnica u Hrvatskoj: prepreke i mogućnosti za promjenu. Bagić, D., Burić, I., Dobrotić I., Potočnik, D., Zrinščak , S. (ur.). Zagreb: UNDP Hrvatska (preuzeto sa: http://www.hr.undp.org/ content/dam/croatia/docs/Research\%20and\%20publications/socialinclusion/undp-hr-roma-everyday-2015.pdf; srpanj 2015).

Vasta, R., Haith, M. M., Miller, S.A. (1998): Dječja psihologija. Jastrebarsko: Naklada Slap. Zakon o predškolskom 
odgoju i obrazovanju, NN 94/13

\section{WEB IZVORI}

Mreža podrške romskoj djeci REYN-Hrvatska (posjećeno u kolovozu 2015); http://reyn-hrvatska.net/

Državni zavod za statisku: Stanovništvo staro 10 i više godina prema spolu, a nepismeni i prema starosti, popis 2001. (posjećeno u kolovozu 2015): http://www.dzs.hr/Hrv/censuses/Census2001/Popis/H01_01_06/ H01_01_06.html

Državni zavod za statistiku: Stanovništvo staro 10 i više godina prema spolu, a nepismeni i prema starosti, popis 2011. (posjećeno u kolovozu 2015): http://www.dzs.hr/Hrv/censuses/census2011/results/ htm/h01_01_33/H01_01_33.html

Program Early Head Start (posjećeno u kolovozu 2015): http://eclkc.ohs.acf.hhs.gov/hslc/tta-system/ ehsnrc/about-ehs

Program Meséd- Mother Telling Stories (posjećeno u kolovozu 2015): http://eaka.hu/en/ storytellingmothers

Program MOCEP- The Mother-Child Home Education Programme (posjećeno u kolovozu 2015): http:// www.unesco.org/uil/litbase/?menu $=9 \&$ programme $=65$

Program Poticajno roditeljstvo, PUO Korak po korak, Izvještaj za 2012. (posjećeno u kolovozu 2015): http://www.korakpokorak.hr/upload/o-nama/izvjestaj-2012.pdf

Program REF-ove biblioteke igračaka u Srbiji (posjećeno u kolovozu 2015): http://www.romanipen. org.rs/projekti/obrazovni-program-za-majku-i-dete/; https://www.facebook.com/pages/REF-ove-bibliotekeigra\%C4\%8Daka-u-Srbiji-REF-Toy-Libraries-in-Serbia/1449611915273979?fref=ts

Test za poznavanje hrvatskog jezika za upis u 1. razred osnovne škole za djecu osnovne škole koja ne znaju ili nedovoljno znaju hrvatski jezik. Nacionalni centar za vanjsko vrednovanje, 2014. (http://ncvvo. $\mathrm{hr}$, posjećeno u prosincu 2015).

\section{ACTIVITIES DIRECTED TOWARD THE EMPOWERMENT OF ILLITERATE PARENTS OF ROMA CHILDREN}

\footnotetext{
Abstract: This paper discusses the relationship between the quality of family environment and the socio-economic status of families with regard to the impact of the impoverished family environment and educational level of parents on the early development of children. In particular it stresses the results of national surveys which indicate that Roma children are one of the most vulnerable groups of children. The paper also presents some practical guidelines for the inclusion of illiterate parents and highlights a number of programs for children of preschool and early school age and their parents from lower SES aimed at encouraging the development of literacy and other cognitive skills in children and empower parents to meet the requirements of their parental role.

As one of the initial steps in the process of enhancing the cooperation and empowerment of Roma children's parents, the paper presents research conducted by teachers and Roma assistants at Tomaš Goričanac Elementary School in Mala Subotica in the Roma settlement of Piškorovec. The main objective of the study was to determine the educational structure and the level of literacy of the adult population in Piškorovec in order to use the results for planning an intervention program which will be based on the assessed needs.
}

Key words: family environment, early childhood development, Roma children, assessment of literacy of parents 